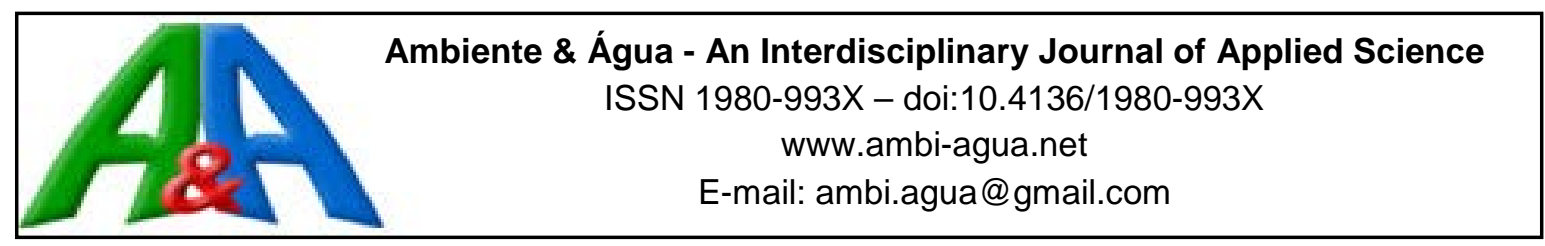

\title{
Integration of treatment technologies with Fenton reagent for laboratory effluent remediation
}

\author{
ARTICLES doi:10.4136/ambi-agua.2243
}

Received: 19 Feb. 2018; Accepted: 08 Jul. 2018

\author{
Chrystopher Allan Miranda Pereira; Núbia Natália Brito* \\ Universidade Federal de Goiás (UFG), Goiânia, GO, Brasil \\ Instituto de Química (IQ). E-mail: chrystophermiranda@gmail.com, nubiabrito@ufg.br \\ ${ }^{*}$ Corresponding author
}

\begin{abstract}
This study investigated of the potential value of the integration of the coagulation/flocculation, Advanced Oxidation Processes (AOP) (Fenton reagent) and slow sand filtration technologies, with the aim of treating laboratory wastewater. The treatment system was designed in laboratory scale through coagulation/flocculation. It involved the use of Jar Test equipment with a sequence of two rotational phases: fast mixes to $300 \mathrm{rpm}$ for 20 seconds and slow mixes to 30 rpm for 6 minutes and 10 seconds, with the addition of anionic polymer and sedimentation for 60 minutes at ambient temperature. In the treatment via Fenton reagent, two rotational phases were used: rapid mixing at $300 \mathrm{rpm}$ for 20 seconds with the addition of iron $\left(\mathrm{Fe}^{2+}\right)$ and slow mixing at 30 rpm for 6 minutes and 10 seconds with the addition of hydrogen peroxide, followed by 60 minutes of sedimentation at ambient temperature. A cylindrical tank of polyvinyl chloride, sands and non-woven synthetic fabrics were used in the slow filtration. The filtration rate adopted was $3 \mathrm{~m}^{3} \mathrm{~m}^{-2} \mathrm{~d}^{-1}$ with a hydraulic retention time of 264 minutes. The best concentrations of chemical reagents used in the treatments were: $0.80 \mathrm{mg} \mathrm{L}^{-1}$ of polymeric anionic, $200.00 \mathrm{mg} \mathrm{L}^{-1}$ of $\mathrm{H}_{2} \mathrm{O}_{2}$ and $13.00 \mathrm{mg} \mathrm{L}^{-1}$ of total soluble iron. The integration of the treatment technologies made it possible to achieve a removal rate of $75.27 \%$ of COD and $94.12 \%$ of total phenols. Furthermore, the conjugation of the processes allowed the removal of $87.58 \%$ of TOC.
\end{abstract}

Keywords: coagulation/flocculation, cosmetics, textile dyes.

\section{Integração de tecnologias de tratamento com reagente de Fenton para remediação de efluente laboratorial}

\section{RESUMO}

Neste trabalho a potencialidade da integração de tecnologias coagulação/floculação, processo oxidativo avançado (reação de Fenton) e filtração lenta foram estudados com o objetivo de tratar resíduo líquido laboratorial apresentando compostos da indústria cosmética e têxtil, principalmente. O sistema de tratamento foi realizado em escala laboratorial através da coagulação/floculação, o equipamento de jarros foi utilizado com uma sequência de duas fases de rotação: mistura rápida a 300 rpm por 20 segundos, mistura lenta a 30 rpm durante 6 minutos e 10 segundos com a adição de polímero aniônico e com um tempo de sedimentação de 60 minutos em temperatura ambiente. No tratamento via reagente de Fenton duas fases de rotação 
foram estudadas: mistura rápida a 300 rpm por 20 segundos com a adição de ferro $\left(\mathrm{Fe}^{2+}\right)$, mistura lenta a 30 rpm durante 6 minutos e 10 segundos com a adição de peróxido de hidrogênio e 60 minutos de sedimentação em temperatura ambiente. Na filtração lenta foi utilizado um tanque cilíndrico de policloreto de vinila, areia e mantas sintéticas não tecidas. A taxa de filtração adotada durantes os experimentos foi de $3 \mathrm{~m}^{3} \mathrm{~m}^{-2} \mathrm{~d}^{-1}$ com um tempo de detenção hidráulica de 264 minutos. As melhores concentrações de reagentes químicos utilizados nos tratamentos foram: 0,80 mg L${ }^{-1}$ de polímero aniônico, 200,00 $\mathrm{mg} \mathrm{L}^{-1}$ de $\mathrm{H}_{2} \mathrm{O}_{2}$ e 13,00 $\mathrm{mg} \mathrm{L}^{-1}$ de ferro solúvel total. A integração das tecnologias de tratamento permitiu a remoção de $75,27 \%$ de DQO e $94,12 \%$ de fenóis totais. Além disso, a conjugação dos processos permitiu remoção de COT de 87,58\%.

Palavras-chave: coagulação/floculação, cosméticos, corantes têxteis.

\section{INTRODUCTION}

The cosmetic industry in Brazil showed a rapid growth up to 2014, compared with other industrial sectors. However, in 2015 the sector showed a decline of about $9 \%$ for the first time in the last 20 years (ABIHPEC, 2017). The cosmetics are produced and used on a massive scale for aesthetic purposes and the huge amount of drinking water used in the refrigeration system, steam generation and particularly for the washing of machines, equipment and utensils, is a cause of concern in the cosmetics industry, since it results in a significant amount of effluent for waste disposal.

According to Banerjee and collaborators (2016), the effluents of the cosmetic industry are harmful from an environmental standpoint; they include high concentrations of organic compounds of slow biodegradability, as well as the presence of anionic surfactants, grease and oils. These impede the aeration of the medium and the transfer of soluble substrates to microorganisms that might have been able to accomplish the degradation of the organic matter and which will hence reduce the rate of the substrate conversion.

Another important industry in Brazil is the dye sector; dyes are widely used in several industrial areas, such as textiles, leather, paper, plastics, foods and rubber for the coloration of their products. Annually more than 10.000 tons of dyes are used, and approximately 100 tons are released into watercourses (Ashrafi et al., 2017).

Water contamination caused by the release of textile dyes can have a considerable impact on the ecosystem. Effluents from the textile industry are considered to be the worst pollutants of water bodies and soils. The dyes cause an undesirable color in the water when they are disposed of without treatment and lead to a reduction of solar radiation, which affects the photosynthetic activity of aquatic organisms (Semeraro et al., 2015).

In addition, the textile dyes are characterized as mutagen agents that are carcinogenic, allergic and cytotoxic and represent a risk to all forms of life (Khandare and Govindwar 2015). Some of them are not biodegradable and undergo biomagnification along the food chain.

The integration of the coagulation/flocculation, advanced oxidation (Fenton reagent) and slow filtration processes was studied in an attempt to remediate the effluents discharged by the laboratory and address the problem outlined above. The effluent mainly contained compounds from the cosmetics and textile industry

\section{MATERIALS AND METHODS}

\subsection{Site of experiments and effluent generation}

The experiments were carried out at the Wastewater Treatment Laboratory, located at the Chemistry Institute, Goiás Federal University, where the coagulation/flocculation, Fenton 
reagent and slow filtration were performed. The analysis to monitor the efficiency of the treatment was carried out in the Residual Wastewater Treatment Laboratory and the Laboratory of Analytical Instrumentation IQ-UFG.

The effluent used in this research was packaged in 50 liter bottles at room temperature and included the following: a liquid by-product of other treatments performed in the Laboratory of Wastewater Treatment, a liquid mixture with chemical compounds in sunscreen, hair conditioners, textile dyes, the analysis of liquid wastewater and environmental procedures carried out by the Wastewater Treatment Laboratory team.

\subsection{Experimental methodology}

In evaluating the rate of efficiency, we carried out analyses in duplicate such as: absorptivity performed at maximum absorption wavelength, turbidity, total residual soluble iron, residual hydrogen peroxide, chemical oxygen demand (COD), oil and greases, $\mathrm{pH}$, total organic carbon (TOC), total solids (TS), total fixed solids (TFS), total volatile solids (TVS) and settleable solids (SS). All the analyses (except residual hydrogen peroxide) complied with the Standard Methods for Examination of Water and Wastewater (SMEWW) 20th Edition (APHA, 1998).

The determination of residual hydrogen peroxide follows procedures adopted by Oliveira et al. (2001), and depend on the reaction between hydrogen peroxide and vanadate ion $\left(\mathrm{VO}_{3}^{-}\right)$ in acid medium. The reaction leads to the formation of peroxovanadium ion $\left(\mathrm{VO}_{2}^{3+}\right)$, which is of a reddish color and absorbs strongly at $446 \mathrm{~nm}$.

The coagulation/flocculation process and the Fenton reaction were performed with jar test equipment using a one-liter volume, and varying rotations between 30 and $300 \mathrm{rpm}$ with sedimentation for 60 minutes. The parameters of rotation and treatment time, as well as the range of initial concentrations of chemical reagents were used for two treatment technologies (coagulation/flocculation and Fenton's reagent) and based on the values of the parameters used in the wastewater treatment station-Goiânia-GO and in Morais and Brito (2015).

The studies of the treatment technology through coagulation/flocculation were initiated using a factorial experimental design $\left(2^{2}\right)$ that was built for experiments 2 levels: a smaller level $(-)$ and larger one $(+)$ for the variables: concentration of anionic polymer $(0.60$ and $1.40 \mathrm{mg} \mathrm{L}^{-1}$ ) and $\mathrm{pH}$ values (6.00 and 8.00); making a total of four experiments.

The treatment with Fenton's reagent to plan a factorial design for the studies was built at $2^{3}$ where there were 2 levels: a smaller level (-) and larger one $(+)$ for the variables: concentration of total soluble iron (2.33 and $\left.6.50 \mathrm{mg} \mathrm{L}^{-1}\right), \mathrm{pH}$ values (3.00 and 5.00) and concentration of peroxide of hydrogen (100.00 and $\left.200.00 \mathrm{mg} \mathrm{L}^{-1}\right)$; making a total of eight experiments.

The dosage of chemical reagents used for the coagulation/flocculation assays ranged from $0.00 \mathrm{mg} \mathrm{L}^{-1}$ to $2.00 \mathrm{mg} \mathrm{L}^{-1}$ of anionic polymer and the $\mathrm{pH}$ values varied from 3.00 to 10.00 . Fenton's reagent treatment concentration of chemical reagents ranged from $2.33 \mathrm{mg} \mathrm{L}^{-1}$ to $90.00 \mathrm{mg} \mathrm{L}^{-1}$ for a total soluble iron concentration, $100.00 \mathrm{mg} \mathrm{L}^{-1}$ to $1200.00 \mathrm{mg} \mathrm{L}^{-1}$ for hydrogen peroxide concentration and a variation in $\mathrm{pH}$ values from 3.00 to 5.50 .

Approximately $200.00 \mathrm{~mL}$ of supernatant liquid were collected from the two treatment systems after sedimentation; values of $\mathrm{pH}$, turbidity, chemical oxygen demand (COD), total residual soluble iron, absorbance and residual hydrogen peroxide (in the case of $\mathrm{H}_{2} \mathrm{O}_{2}$ residual, only in treatment via Fenton's reaction) were measured to determine the efficiency of the treatment through variations in the values of these parameters during the treatment operations.

The COD determination was performed after an increase of $\mathrm{pH}$ to 8.00 and the sample was then heated to $80^{\circ} \mathrm{C}$ for 40 minutes to remove residual $\mathrm{H}_{2} \mathrm{O}_{2}$. The sample remained at rest for 2 hours (ambient temperature) to sediment residual iron that interferes with the result (Cavalcante, 2005).

\section{IPABH}

Rev. Ambient. Água vol. 13 n. 5, e2243 - Taubaté 2018 
A cylindrical tank made of PVC (polyvinyl chloride) with a height of $55.00 \mathrm{~cm}$ and a diameter of $14.50 \mathrm{~cm}$ was used to construct a slow filter. The collection system, which also consisted of a PVC pipe, originated from the drainage system that follows the sand layer described above. Thus it was able to avoid the occurrence of negative pressure and, hence, the accumulation of air inside the filter medium, as well as ensuring the constant presence of effluent inside the filter. The adopted rate was $3 \mathrm{~m}^{3} \mathrm{~m}^{-2} \mathrm{~d}^{-1}$ and this was monitored periodically by the volumetric method of analysis.

The thickness of the filter material consisted of a $20 \mathrm{~cm}$ layer of fine sand used in civil engineering, followed by $5 \mathrm{~cm}$ of $\mathrm{n}^{0} 2$ crushed stone used as a support layer. The sand was washed with water and dried in the environment with solar radiation after being placed in a slow filter.

A non-woven synthetic blanket of brand GeotêxtilGeoFort GF Model 17 was placed between the crushed stone layer and the sand layer. Its features were as follows: $95.70 \%$ porosity, specific surface of $2.530 \mathrm{~m}^{2} \mathrm{~m}^{-3}$, weight $400 \mathrm{~g} \mathrm{~m}^{-2}$, thickness of $3 \mathrm{~mm}$ and $100 \%$ polypropylene composition to prevent sand from permeating the crushed stone. At the top of the sand layer, two non-woven synthetic blankets (Model 17) were used to prolong the effective time of the filter media and make the "schmutzdecke" development more efficient. The treatment began on June 13, 2016 at 1:00 p.m. and the treatment lasted for 264 minutes.

The slow filter was operated with a sample of effluent, batch processing system. The analyses were only employed for the monitoring of the treatment efficiency after some preliminary tests had been carried out. This was accomplished so that the filter could acquire a period of biological development and maturation.

The stages of the research treatment of the technologies tested are separated in the way shown in Figure 1 which represents the crude laboratory effluent involving a primary treatment through coagulation/flocculation, and subsequently a secondary treatment with Fenton's reagent and concluding with the slow filtration to provide final polishing.

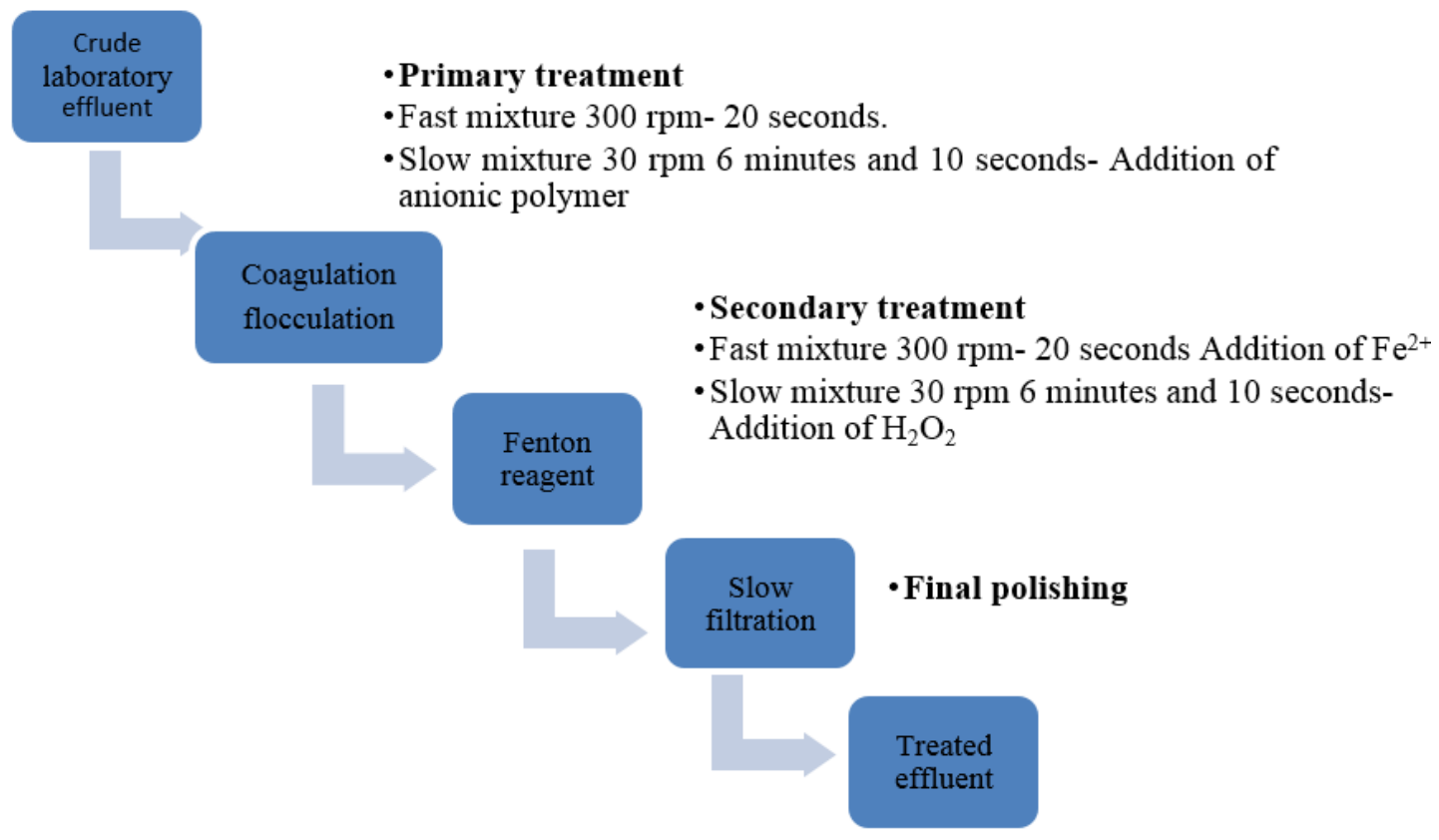

Figure 1. Treatment flowchart: Coagulation/flocculation, Fenton reagent and slow sand filtration.

As already explained, the studies began with the treatment technology through coagulation/flocculation so that a factorial experimental design $\left(2^{2}\right)$ planned for the variables: 
concentration of anionic polymer (0.60 and $1.40 \mathrm{mg} \mathrm{L}^{-1}$ ) and $\mathrm{pH}$ values (6.00 and 8.00); subsequently the dosage of chemical reagents for the coagulation/flocculation assays ranged from $0.00 \mathrm{mg} \mathrm{L}^{-1}$ to $2.00 \mathrm{mg} \mathrm{L}^{-1}$ of anionic polymer and the $\mathrm{pH}$ values varied from 3.00 to 10.00 .

Before starting the treatment with Fenton's reagent for the study, a factorial experimental design $\left(2^{3}\right)$ was planned for the variables: concentration of total soluble iron ( 2.33 and $\left.6.50 \mathrm{mg} \mathrm{L}^{-1}\right), \mathrm{pH}$ values (3.00 and 5.00) and concentration of peroxide of hydrogen (100.00 and $\left.200.00 \mathrm{mg} \mathrm{L}^{-1}\right)$; subsequently the concentration of chemical reagents ranged from $2.33 \mathrm{mg} \mathrm{L}^{-1}$ to $90.00 \mathrm{mg} \mathrm{L}^{-1}$ for total soluble iron concentration, $100.00 \mathrm{mg} \mathrm{L}^{-1}$ to $1200.00 \mathrm{mg} \mathrm{L}^{-1}$ for hydrogen peroxide concentration and the $\mathrm{pH}$ values varied from 3.00 to 5.50 .

The total treatment time was 400 minutes for the integration of the technologies. At the end of the combined treatment stages, the treatment efficiency was monitored through an environmental control system and further studies on classification of treated effluent for disposal and non-potable reuse purposes were carried out in compliance with the following resolutions: Conama (2005;2011), AGR (2009), ABNT (1997) and USEPA (2012).

\subsection{Characterization of crude effluent}

A characterization of effluent was carried out, which provided average and standard deviations from the calculations made with five different samples that are illustrated in Table 1 .

Table 1. Average values and standard deviation of the analyzed physicochemical parameters for crude laboratory liquid residue.

\begin{tabular}{lccc}
\hline Parameters & Values & $\begin{array}{c}\text { Crude laboratory } \\
\text { effluent }\end{array}$ & $\begin{array}{c}\text { Resolution } \\
\text { Conama (2005; 2011); AGR (2009) }\end{array}$ \\
\hline pH & Average & 1.73 & $5-9$ \\
Turbidity (NTU) & Standard deviation & 0.06 & $100 \mathrm{NTU}$ \\
& Average & 134.40 & \\
Absorbance (320nm) & Standard deviation & 24.96 & \\
& Average & 1.60 & $450.00 \mathrm{mg} \mathrm{O}_{2} \mathrm{~L}^{-1}$ \\
COD (mg O $\mathbf{~ L}^{-1}$ ) & Standard deviation & 0.40 & $15.00 \mathrm{mg} \mathrm{L}^{-1}$ \\
Soluble Total & Average & 1400.49 & \\
Residual Iron (mg L & Standard deviation & 436.53 & \\
\hline
\end{tabular}

The main parameter that needs to be monitored is the removal of the organic matter represented in this study by the COD. The Brazilian Resolution of 2011 (Conama, 2011) does not specify a COD value for effluent discharge, but only for BOD with a minimum removal of 60\%. The Brazilian Resolution of 2009 (AGR, 2009) stipulates a COD maximum value of $450.00 \mathrm{mg} \mathrm{O}_{2} \mathrm{~L}^{-1}$ for wastewater discharge. In this article, crude laboratory effluent had a COD value of, on average, $1400.49 \mathrm{mg} \mathrm{O}_{2} \mathrm{~L}^{-1}$, which is also outside the standards for hydraulic bodies.

In light of the data, we believe that the integration of the proposed technologies gives a promising opportunity for the treatment of recalcitrant effluents.

\section{RESULTS AND DISCUSSION}

\subsection{Coagulation/Flocculation treatment}

The most interesting results obtained in the preliminary tests $\left(2^{2}\right.$ factorial planning) were anionic polymer concentration $0.60 \mathrm{mg} \mathrm{L}^{-1}$ and $\mathrm{pH}$ value 6.00 (31.16\% COD removal), where the negative charges of the effective particles which led to chemical interactions were 
neutralized, thus causing the formation of flake and incurring a lower cost, compared with the high cost of the chemical reagents involved in the process.

After making a choice of these data, the variation of anionic polymer concentration was studied, with $\mathrm{pH}$ value fixed at 6.00 and concentration of total soluble iron $82.49 \mathrm{mg} \mathrm{L}^{-1}$ (natural concentrations of effluent) to obtain maximum efficiency in treatment, as can be seen in Figure 2.

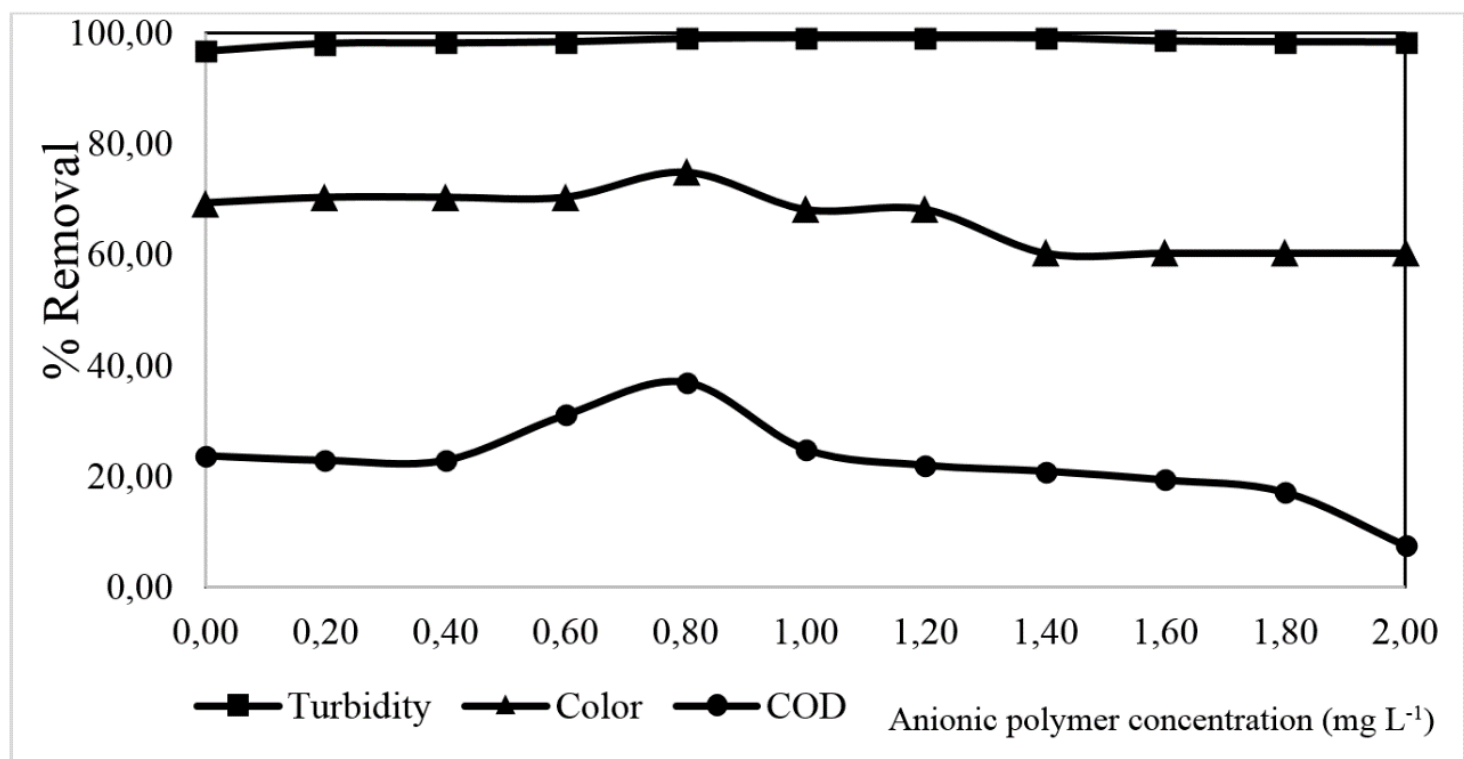

Figure 2. Effect of variation of anionic polymer concentration on COD, turbidity and absorbance removals by coagulation/flocculation treatment (pH 6.00 and residual total soluble iron $=82.49 \mathrm{mg} \mathrm{L}^{-1}$ ).

It can be observed in Figure 2 that COD removal remained constant at $23.00 \%$ up to $0.40 \mathrm{mg} \mathrm{L}^{-1}$, and it did not show any significant results in this range with the use of anionic polymer.

The removal of the organic matter increased around $11 \%$ when there was a concentration of polymeric anionic of $0.80 \mathrm{mg} \mathrm{L}^{-1}$, which is a considerable value for treating recalcitrant compounds.

It is worth noting that this dosage of polymeric anionic also contributes significantly to the cohesion of the flake, since a better interaction of the iron ions prevents them from being released into the water bodies (Shaikh et al., 2017). An example of this was the removal of iron (in these conditions) of $97.17 \%$. The initial iron concentration was $82.49 \mathrm{mg} \mathrm{L}^{-1}$ and the final concentration was $2.33 \mathrm{mg} \mathrm{L}^{-1}$. This is because the polymer chains are able to adopt multiple conformations on the adsorbent surface, which distinguishes their adsorption behavior from that of simple molecules and ions (Wiśniewska et al., 2016). In this way, the soluble iron concentration also reaches parameters for disposal that comply with Brazil Resolution 2011 (Conama, 2011) which provides a maximum of $15 \mathrm{mg} \mathrm{L}^{-1}$ of total iron for disposal in hydric bodies.

It was found that when there was a concentration above $1.00 \mathrm{mg} \mathrm{L}^{-1}$, it led to a reduction in the percentage of COD removal efficiency observed, which proves that an excess of anionic polymer led to an increase of solids, especially colloidal and particulate material. The excess of anionic polymers re-stabilizes the charge on colloidal particles by saturating its surface, damaging the formation of flocks in flocculation process and increasing the concentration of particulate matter in the effluent (Quartaroli et al., 2014). 
During the removal of the color as a result of absorbance, measured at the maximum absorption wavelength (spectral sweep) $320 \mathrm{~nm}$, it was noted that without the addition of an anionic polymer, a removal of $70.51 \%$ was obtained. With the addition of the anionic polymer, the maximum rate of efficiency for the removal of this parameter was $75.00 \%$, with $0.80 \mathrm{mg} \mathrm{L}^{-1}$ of anionic polymer. A decrease in the absorbance removal rate of efficiency of $1.00 \mathrm{mg} \mathrm{L}^{-1}$ resulted in an excess of anionic polymer which led to an increase of solids interfering with absorption of the medium, and hence color parameter (Quartaroliet al., 2014).

With regard to the analysis of turbidity, it was observed that the turbidity remained almost constant with a mean rate of removal for all concentrations of anionic polymer. It should be noted that without the addition of the anionic polymer, there is a removal efficiency rate of around $96.80 \%$, which is evidence that anionic polymer does not interfere in the removal of turbidity. It is only the presence of total soluble iron in residue and the suitable adjustment of $\mathrm{pH}$ that are sufficient for the removal of suspended and colloidal particles that cause turbidity in this effluent.

This fact can be explained by the formation of ferrous and ferric hydroxides of positive residual charge. These hydroxides, (also called gel), destabilize the colloidal particles of the effluent that possess a negative load, by reducing the potential Zeta and allow the approach and clustering of these particles, which characterizes the coagulation/flocculation process. It is also important to point out that there is a displacement of the chemical equilibrium when the $\mathrm{pH}$ increases to 6.00, which allows the formation of hydroxylated species, as is illustrated in Equation 1 (Morais and Brito 2016; Shaikh et al., 2017).

$\mathrm{Fe}^{2+}+2 \mathrm{H}_{2} \mathrm{O} \leftrightarrows \mathrm{Fe}(\mathrm{OH})_{2}+2 \mathrm{H}^{+}$

In view of the obtained data, it was confirmed that the optimum concentration of anionic polymer was $0.80 \mathrm{mg} \mathrm{L}^{-1}$, and an attempt was made to evaluate the influence of $\mathrm{pH}$ values on the efficiency of the treatment. At this stage, the $\mathrm{pH}$ values were found to be in the range of 3.00 to 10.00 with total soluble iron concentration of $82.49 \mathrm{mg} \mathrm{L}^{-1}$ and anionic polymer of $0.80 \mathrm{mg} \mathrm{L}^{-1}$ (Figure 3).

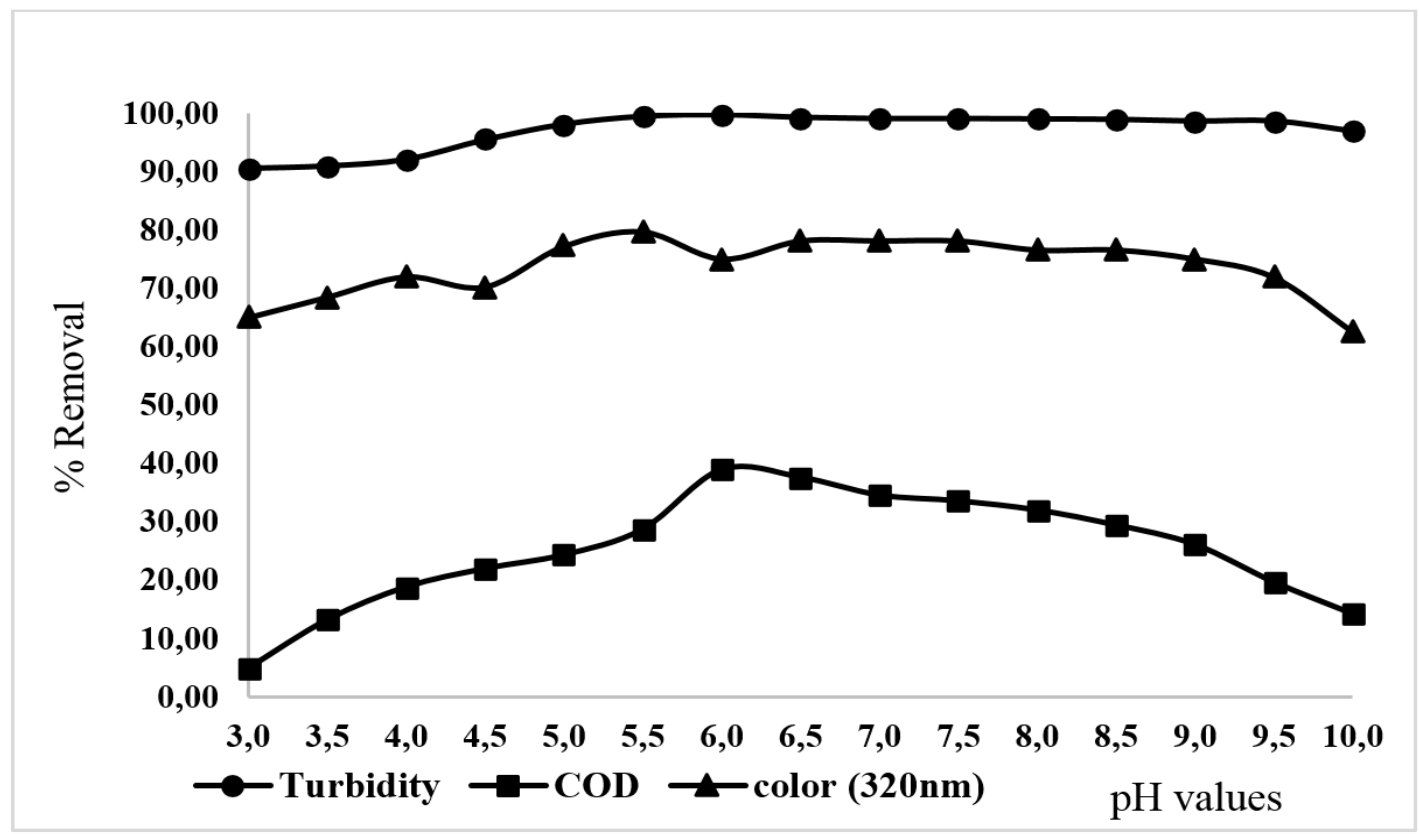

Figure 3. The effect of the variation of the $\mathrm{pH}$ values on COD, turbidity and absorbance removals for the treatment with coagulation/flocculation (total soluble iron $=82.49 \mathrm{mg} \mathrm{L}^{-1}$; anionic polymer $=0.80 \mathrm{mg} \mathrm{L}^{-1}$ ). 
In the case of the analysis of COD, the best percentage for removal (38.86\%) occurred at $\mathrm{pH}$ 6.00, because the polyacrylamide chains were completely ionized. As a result, there was an interaction of the anionic polymer with surface of flake mainly through the formation of hydrogen bonds between them (Wiśniewska et al., 2016).

The interactions between adsorbed species and surface hydroxyl groups, (whether protonated or not), altered the resulting charge of the particles and hence, the stability of suspension conditions. When $\mathrm{pH}$ of the solution is greater than the zero point charge of the solid in question (hydroxylated iron species), the surface of the solution becomes negative. This discourages electrostatic interactions with polyacrylamide polymer chains (since they contain completely dissociated carboxyl groups); this phenomenon may be occurring in this study when $\mathrm{pH}$ is above 6.00 (Wiśniewska et al., 2016).

With regard to the absorbance analysis at $320 \mathrm{~nm}$, it can be seen that the removal efficiency at $\mathrm{pH} 6.00$ was $75.00 \%$ on average, with removals up to $78.00 \%$ (pH values between $5.00-7.50$ ) which can also be visualized, although when analyzing a set of three parameters, the choice of the best $\mathrm{pH}$ value was 6.00. At $\mathrm{pH}$ less than 4.50, there is a decrease in removal efficiency, with a removal efficiency of $64.91 \%$.

When this occurs, low $\mathrm{pH}$ values (less than 5.00), and aquo-complexes $\left[\mathrm{Fe}\left(\mathrm{H}_{2} \mathrm{O}\right)_{6}\right]^{3+}$ are predominant, while the hydroxylated $\mathrm{Fe}(\mathrm{OH})^{2+}$ species is generally at a $\mathrm{pH}$ greater than 4.00 (Gama, 2012). The Fe $(\mathrm{OH})^{2+}$ species displays maximum absorbance with wavelengths of $300 \mathrm{~nm}$, extending up to approximately $400 \mathrm{~nm}$ (Nogueira et al., 2007).

In the case of the turbidity analysis, it can be observed in Figure 3 that the percentages or removals were similar to the $\mathrm{pH}$ values studied, with results of reduction around $99.00 \%$. A maximum removal rate at $\mathrm{pH} 6.00$ was obtained of around $99.72 \%$.

When there is $\mathrm{pH}$ of 3.00 to 5.50 , turbidity has a smaller point of removal. It has been shown that at higher $\mathrm{pH}$ values ( $>5.50$ ), a displacement of the hydrolysis equilibrium of iron ions is achieved, leading to the formation of iron hydroxides that are essential for the interaction with colloids and formation of flakes (Guo et al., 2010).

A better operating condition was obtained from the results of the $\mathrm{pH}$ variation, where $82.49 \mathrm{mg} \mathrm{L}^{-1}$ of total soluble iron and $0.80 \mathrm{mg} \mathrm{L}^{-1}$ of anionic polymer were used in a $\mathrm{pH}$ value of 6.00; this made it possible to reach COD removals of $38.86 \%$, turbidity of $99.72 \%$ and absorbance of $75.00 \%$.

After the coagulation/flocculation treatment and the results were obtained for $\mathrm{pH}$ value, the turbidity and total iron were in accordance with the effluent release standards established by Brazil 2011 (Conama, 2011), with the exception of the COD parameter (856.26 $\mathrm{mg} \mathrm{O}_{2} \mathrm{~L}^{-1}$ ) that had values above those allowed by the Brazil 2009 Resolution (AGR, 2009), at $450.00 \mathrm{mg} \mathrm{O}_{2} \mathrm{~L}^{-1}$.

Thus, treatment must be provided via the Fenton reagent that can be combined with the coagulation/flocculation process, mainly to reduce the values related to chemical oxygen demand, that even after treatment by coagulation/flocculation still fail to meet the current standards for the discharge of effluents in water bodies, and hence would not be suitable for reuse for non-potable purposes.

\subsection{Fenton reagent treatment}

After the coagulation/flocculation treatment, the best test obtained from the Fenton reagent assays, was used to meet the standards and established values laid down by the studied resolutions. The residual total soluble iron $2.33 \mathrm{mg} \mathrm{L}^{-1}$ obtained from the previous treatment (coagulation / flocculation) was used for the factorial design, which avoided the unnecessary use of chemical reagents. 
Preliminary tests were conducted using a $2^{3}$ factorial planning design (two levels and three variables), since this had the highest removal efficiency for COD (29.82\%), and is the most important parameter, given the difficulty of its removal and its estimated representation of organic matter. In the case of the other parameters, the results were turbidity $(65.00 \%)$, absorbance (40.00\%) and final $\mathrm{pH}$ of 2.83. In this experiment, $6.50 \mathrm{mg} \mathrm{L}^{-1}$ of total soluble iron and $200.00 \mathrm{mg} \mathrm{L}^{-1}$ of $\mathrm{H}_{2} \mathrm{O}_{2}$ were used at an initial $\mathrm{pH}$ of 3.00 .

From the data produced by the factorial design, the total soluble iron concentration, $\mathrm{H}_{2} \mathrm{O}_{2}$ and $\mathrm{pH}$ values were varied to determine the best conditions for the Fenton reaction in the treatment of laboratory effluent after coagulation/flocculation, starting with a concentration of total soluble iron (2.33 to $90.00 \mathrm{mg} \mathrm{L}^{-1}$ ) maintaining $\mathrm{H}_{2} \mathrm{O}_{2}$ at $200.00 \mathrm{mg} \mathrm{L}^{-1}$ and $\mathrm{pH}$ at 3.00 .

In Figure 4, it was clear that the COD removal values had maximum values in $13.00 \mathrm{mg} \mathrm{L}^{-1}$ concentration of total soluble iron (COD 32.37\%). When concentrations below $13.00 \mathrm{mg} \mathrm{L}^{-1}$ of total soluble iron were analyzed, there was a loss of efficiency, caused by the low concentration of iron species capable of reacting with $\mathrm{H}_{2} \mathrm{O}_{2}$, and this reduced the generation of hydroxyl radicals in the medium.

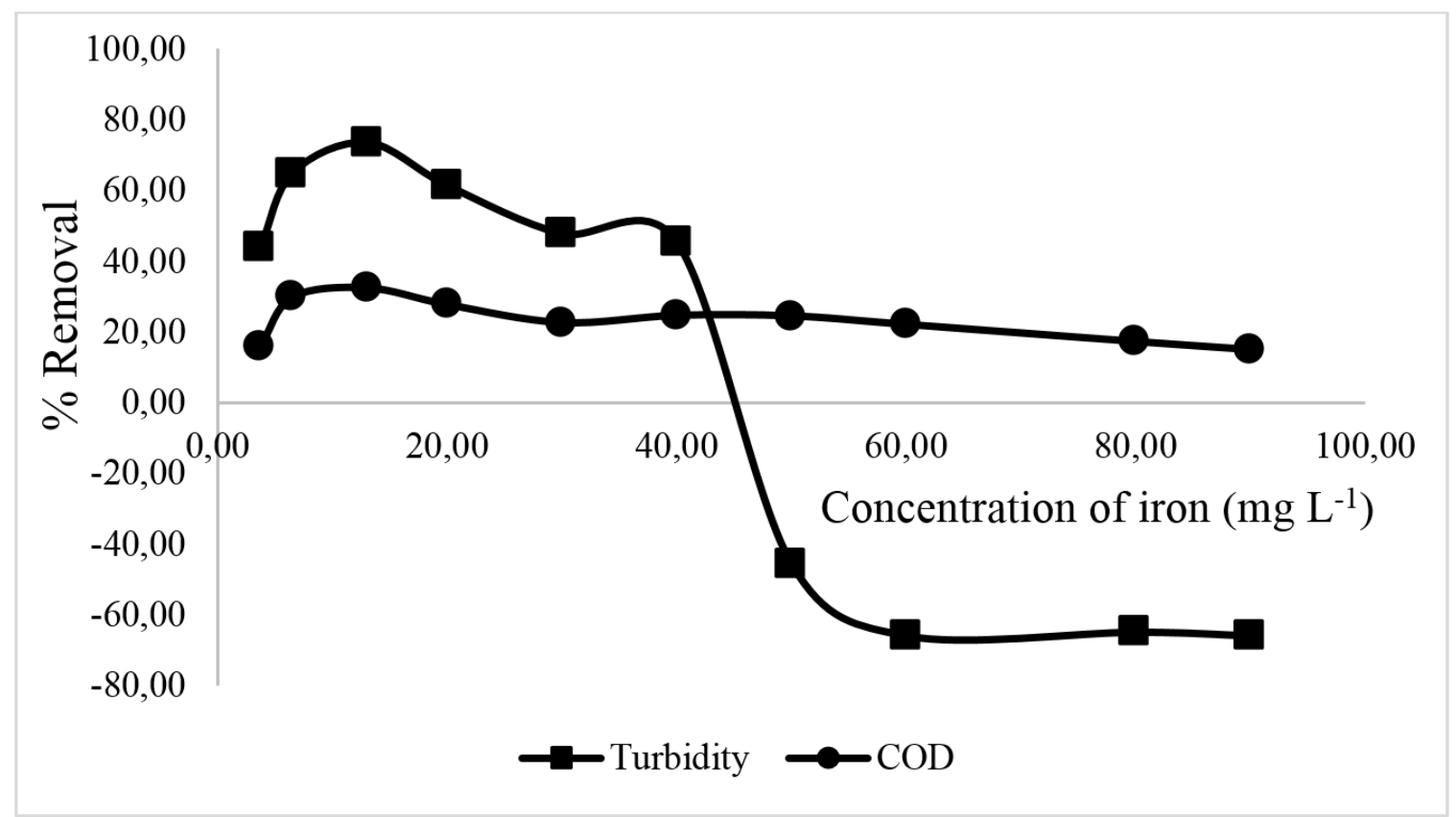

Figure 4. Effect of total soluble iron concentration on COD and turbidity removals through treatment with the Fenton reagent $\left(\mathrm{H}_{2} \mathrm{O}_{2}=200.00 \mathrm{mg} \mathrm{L}^{-1}\right.$, $\left.\mathrm{pH} 3.00\right)$. Note: the negative (-) signals represent an increase in value of the parameter in question.

When going beyond a concentration of $13.00 \mathrm{mg} \mathrm{L}^{-1}$, there begins to be a decline in efficiency in the removal of organic matter. This is due to an increase in concentration of $\mathrm{Fe}^{+2}$ that sequesters hydroxyl radicals, producing $\mathrm{Fe}^{3+}$ and $\mathrm{OH}^{-}$ions, as expressed in Equation 2 (Ma and Xia, 2009).

$\mathrm{Fe}^{2+}+\mathrm{HO}^{\bullet} \rightarrow \mathrm{Fe}^{3+}+\mathrm{HO}^{-}$

$$
\mathrm{K}=2.5-5 \times 10^{8} \mathrm{~L} \mathrm{~mol}^{-1} \mathrm{~s}^{-1}
$$

Because the kinetic constant $\left(2.5-5 \times 10^{8} \mathrm{~L} \mathrm{~mol}^{-1} \mathrm{~s}^{-1}\right)$ is higher than the Fenton reaction Phase 1 reaction (Equation 2), the excess of $\mathrm{Fe}^{+2}$ in the system prefers the reaction represented by Equation 1 to the reaction of Equation 3, which confirms the negative result of the high increase in the concentration of $\mathrm{Fe}^{+2}$ in the treatment.

$\mathrm{Fe}^{2+}+\mathrm{H}_{2} \mathrm{O}_{2}+\mathrm{H}^{+} \rightarrow \mathrm{Fe}^{3+}+\mathrm{HO}^{\bullet}+\mathrm{H}_{2} \mathrm{O}$

40-80 $\mathrm{L} \mathrm{mol}^{-1} \mathrm{~s}^{-1}$

\section{IPABH}

Rev. Ambient. Água vol. 13 n. 5, e2243 - Taubaté 2018 
In an analysis of turbidity, it can be seen that an excessive increase of concentration of $\mathrm{Fe}^{+2}$ leads to a decrease in efficiency with regard to the removal of suspended/colloidal particles; this is shown in the graph of Figure 4, where there is a concentration of around $50.00 \mathrm{mg} \mathrm{L}^{-1}$ of total soluble iron. This behavior can be explained by the oxidation of $\mathrm{Fe}^{+2}$ to $\mathrm{Fe}^{+3}$ which, by hydrolysis in aqueous solution, leads to the formation of iron and ferric hydroxides, which cause increased turbidity in the treated effluent, as shown in Equations 4, 5 and 6 (Morais and Brito, 2016).

$$
\begin{aligned}
& \mathrm{Fe}^{3+}+6 \mathrm{H}_{2} \mathrm{O} \leftrightarrows\left[\mathrm{Fe}\left(\mathrm{H}_{2} \mathrm{O}\right)_{6}\right]^{3+} \\
& {\left[\mathrm{Fe}\left(\mathrm{H}_{2} \mathrm{O}\right)_{6}\right]^{3+}+\mathrm{H}_{2} \mathrm{O} \leftrightarrows\left[\mathrm{Fe}\left(\mathrm{H}_{2} \mathrm{O}\right)_{5} \mathrm{OH}\right]^{2+}+\mathrm{H}_{3} \mathrm{O}^{+}} \\
& {\left[\mathrm{Fe}\left(\mathrm{H}_{2} \mathrm{O}\right)_{5} \mathrm{OH}\right]^{2+}+\mathrm{H}_{2} \mathrm{O} \leftrightarrows\left[\mathrm{Fe}\left(\mathrm{H}_{2} \mathrm{O}\right)_{4}(\mathrm{OH})_{2}\right]^{+}+\mathrm{H}_{3} \mathrm{O}^{+}}
\end{aligned}
$$

Figure 4 shows that keeping the concentration of $\mathrm{H}_{2} \mathrm{O}_{2}$ at $200.00 \mathrm{mg} \mathrm{L}^{-1}$ and $\mathrm{pH} 3.00$ with a concentration of total soluble iron at $13.00 \mathrm{mg} \mathrm{L}^{-1}$ enabled the removal of COD to reach around $32.37 \%$, with turbidity of $73.53 \%$ and final $\mathrm{pH}$ of 2.95 . At the end of the treatment, the residual total soluble iron concentration was found to be $6.40 \mathrm{mg} \mathrm{L}^{-1}$, which is within the release standards established by Brazil (Conama, 2011) (i.e., $15.00 \mathrm{mg} \mathrm{L}^{-1}$.).

In the next stage of the treatment, the influence of $\mathrm{pH}$ values was evaluated, and values of total soluble iron at $13.00 \mathrm{mg} \mathrm{L}^{-1}$ and $\mathrm{H}_{2} \mathrm{O}_{2}$ at $200.00 \mathrm{mg} \mathrm{L}^{-1}$ (Figure 5) were maintained.

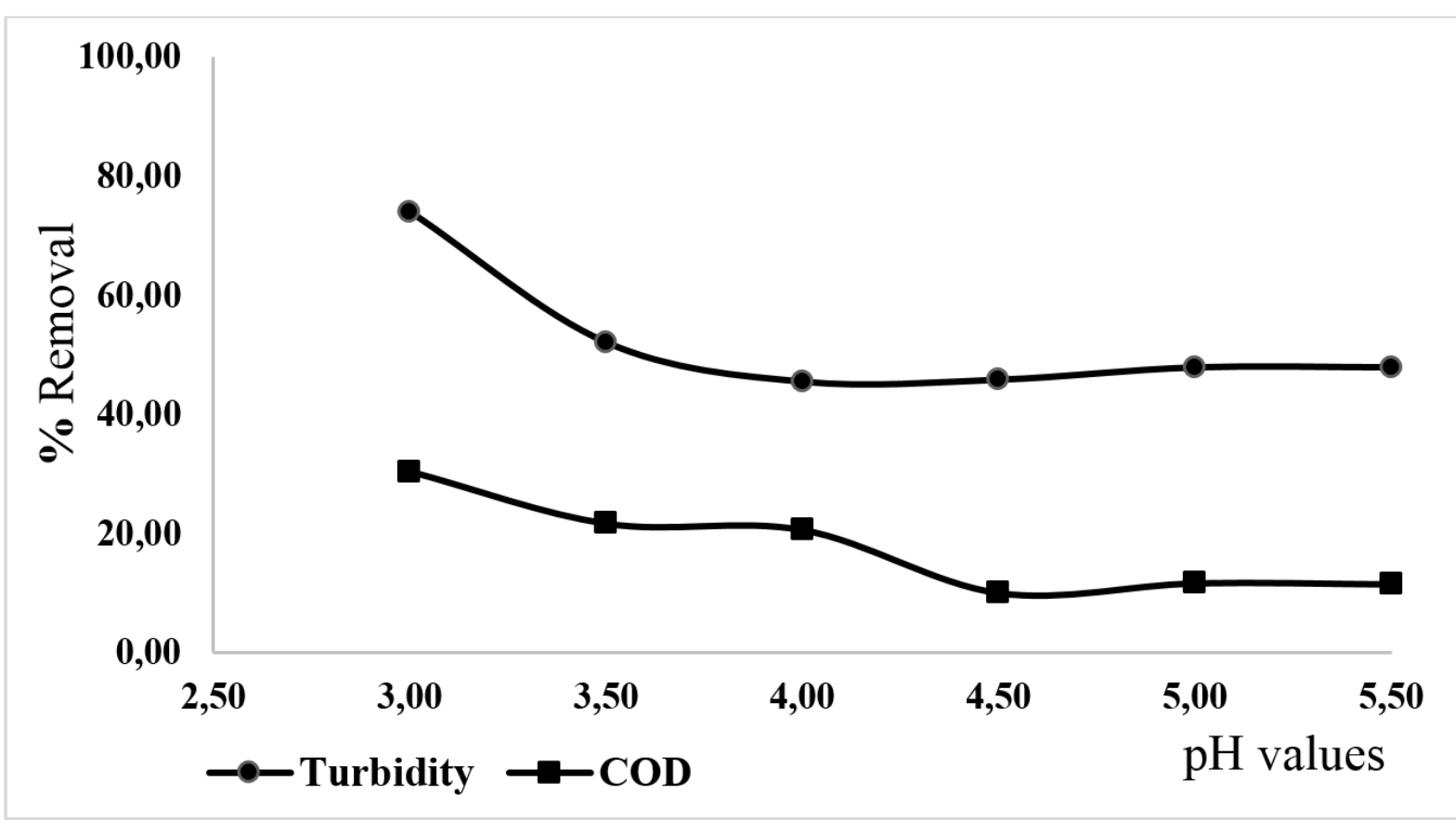

Figure 5. Effect of the variation of the $\mathrm{pH}$ values on $\mathrm{COD}$ and turbidity removals for the treatment with Fenton reagent (total soluble iron $=13.00 \mathrm{mg} \mathrm{L}^{-1} ; \mathrm{H}_{2} \mathrm{O}_{2}=200.00 \mathrm{mg} \mathrm{L}^{-1}$ ).

The efficiency removal rates of COD values (30.40\%) and turbidity (74.00\%), showed maximum values at $\mathrm{pH} 3.00$. The treatment has a higher degree of efficiency in the acid range between $\mathrm{pH} 3-4$, by directly increasing the concentration of $\mathrm{Fe}^{2+}$ in solution and the availability of the hydroxyl radicals in the medium (Lin et al., 2016).

The efficiency of Fenton reagent depends on the formation of the hydroxyl radicals shown in Equation 3 and the increase of $\mathrm{H}^{+}$ions induces the consumption of $\mathrm{OH}^{-}$ions by undergoing a displacement in the equation for the formation of hydroxyl radicals (Mirzaei et al., 2017). 
When there was a $\mathrm{pH}$ value higher than 4.50, a decrease in COD removal percentage was observed, owing to the decrease of free iron species, together with formation of complex species and iron precipitates, as well as the degradation of $\mathrm{H}_{2} \mathrm{O}_{2}$ to $\mathrm{O}_{2}$ and $\mathrm{H}_{2} \mathrm{O}$ or the formation of anion $\mathrm{HO}_{2}{ }^{-}$(Torradesa and Montañob, 2014). In conditions when there are neutral $\mathrm{pH}$ values, the reduction of $\mathrm{H}^{+}$ions is induced, which reduces the productive efficiency of the hydroxyl radical.

According to Nogueira et al. (2007), when the $\mathrm{pH}$ value is smaller than 3.00, the rate of degradation also decreases, although iron species remains soluble, since high concentrations of $\mathrm{H}^{+}$can sequester hydroxyl radicals, as shown in Equation 7:
$\mathrm{HO}^{\bullet}+\mathrm{H}^{+}+e^{-} \rightarrow \mathrm{H}_{2} \mathrm{O}$
$7 \times 10^{9} \mathrm{~L} \mathrm{~mol}^{-1} \mathrm{~s}^{-1}$

In the last stage of Fenton's reagent, different concentrations of $\mathrm{H}_{2} \mathrm{O}_{2}$ were observed with constant values of total soluble iron of $13.00 \mathrm{mg} \mathrm{L}^{-1}$ and $\mathrm{pH} 3.00$. The results for the variations of hydrogen peroxide are shown in Figure 6.

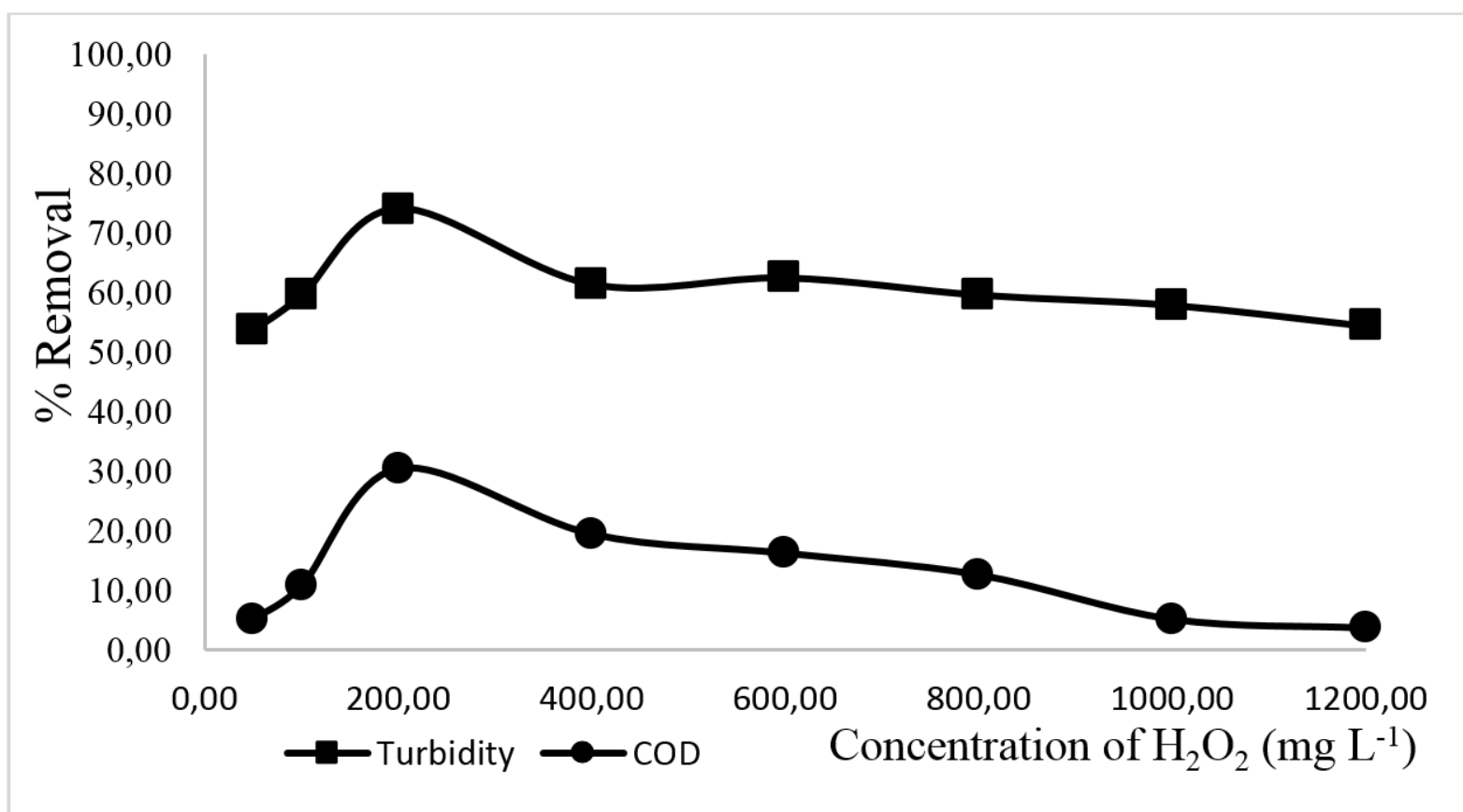

Figure 6. Effect of $\mathrm{H}_{2} \mathrm{O}_{2}$ concentration on COD and turbidity removals through treatment with Fenton reagent (Total soluble iron $=13.00 \mathrm{mg} \mathrm{L}^{-1}$, $\mathrm{pH} 3.00$ ).

In the analysis of Figure 6, it was confirmed that concentrations of $200.00 \mathrm{mg} \mathrm{L}^{-1}$ of $\mathrm{H}_{2} \mathrm{O}_{2}$ increase the removal of COD and turbidity; COD has a reduction efficiency of $30.40 \%$ and turbidity of $74.00 \%$. Values greater than $200.00 \mathrm{mg} \mathrm{L}^{-1}$ reduce the removal efficiency, and have a negative effect on a high concentration of hydrogen peroxide, which reacts with hydroxyl radical and forms a hydroperoxyl radical (Equation 8) (Brito et al., 2010).

$$
\mathrm{HO}^{\bullet}+\mathrm{H}_{2} \mathrm{O}_{2} \rightarrow \mathrm{HO}_{2}^{\bullet}+\mathrm{H}_{2} \mathrm{O} \quad \mathrm{K}=1.7-4.5 \times 10^{7} \mathrm{~L} \mathrm{~mol}^{-1} \mathrm{~s}^{-1}
$$

In addition to reacting to hydrogen peroxide, as is shown in Equation 9, hydroxyl radicals can react with each other, by regenerating hydrogen peroxide (eq 9), and reducing concentrations of the radical in the medium and reducing the efficiency of the Fenton reaction (Brito et al., 2010).

\section{IPABH}


$\mathrm{HO}^{\bullet}+\mathrm{HO}^{\bullet} \rightarrow \mathrm{H}_{2} \mathrm{O}_{2}$

$\mathrm{K}=5-8 \times 10^{9} \mathrm{~L} \mathrm{~mol}^{-1} \mathrm{~s}^{-1}$

Ragasson (2013) specifies that the typical ratio of $\left[\mathrm{Fe}^{+2}\right]$ and $\left[\mathrm{H}_{2} \mathrm{O}_{2}\right]$ is in the range of 1:5 to 1:10 for greater efficiency of Fenton reagent; however, this ratio depends on the nature of the effluent and its organic load.

After the reagent Fenton treatment for laboratory effluent, the relation between $\mathrm{Fe}^{2+}$ ions and hydrogen peroxide was 1:15.38.

These concentrations was varied to determine the ideal concentrations of iron and hydrogen peroxide, which are always around the ratio 1:15 of soluble iron and hydrogen peroxide (the best ratio that has been found in this article), as shown in Figure 7.

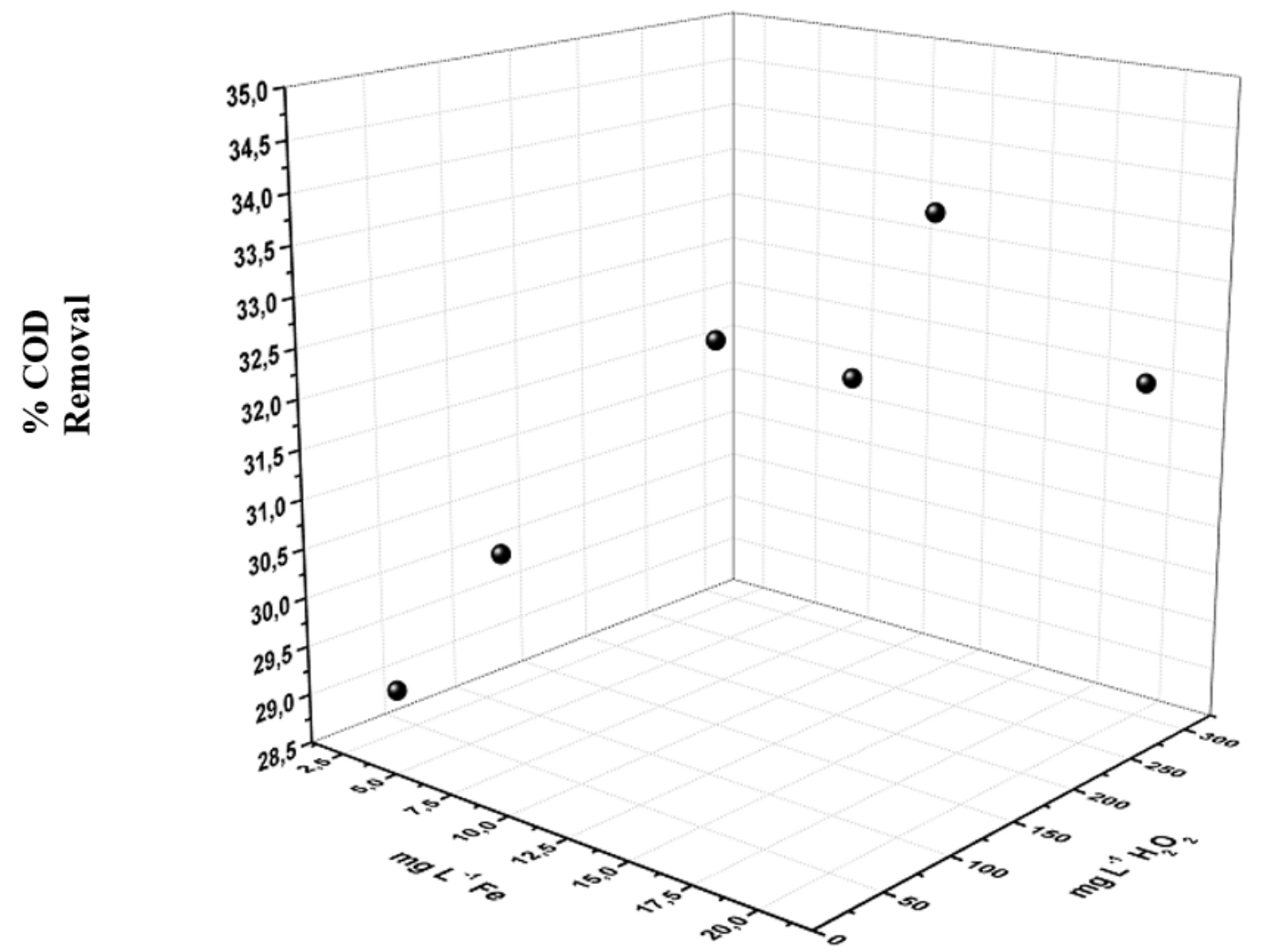

Figure 7. Study of Fe: $\mathrm{H}_{2} \mathrm{O}_{2}$ ratio in COD removal using the ratio obtained (1:15).

From the perspective of the Fe: $\mathrm{H}_{2} \mathrm{O}_{2}$ (ratio of 1:15) COD removals ranged from $28.94 \%$ to $33.70 \%$. It was decided to keep total soluble iron concentrations of $13.00 \mathrm{mg} \mathrm{L}^{-1}$ and $\mathrm{H}_{2} \mathrm{O}_{2}$ of $200.00 \mathrm{mg} \mathrm{L}^{-1}$ with a removal percentage of around 32.05\% COD. At concentrations of 15.00 mg L ${ }^{-1}$ of total soluble iron and $\mathrm{H}_{2} \mathrm{O}_{2}$ of $225.00 \mathrm{mg} \mathrm{L}^{-1}$, a COD removal of $33.70 \%$ was achieved; however, the increase of only $2.00 \%$ does not compensate for the extra expense of the chemical reagents.

The selected concentration of $13.00 \mathrm{mg} \mathrm{L}^{-1}$ of total soluble iron may indicate whether there was removal of iron at the end of the slow filtration, by taking into account the assimilation of iron and manganese by the microbial consortium formed at the top of the layer of the filter bed called "schmutzdecke" and the adsorption of metals in microbial beds and from the formed biofilm in the sand layers (Arantes et al., 2014).

On the basis of the study of the variables that had a direct influence on Fenton's reagent treatment, it could be concluded what was the optimal concentration in removal of both COD (30.40\%) and turbidity (74.00\%) - using $200.00 \mathrm{mg} \mathrm{L}^{-1}$ of hydrogen peroxide and $13.00 \mathrm{mg} \mathrm{L}^{-1}$ of total soluble iron. With regard to $\mathrm{pH}$, its greater efficiency was obtained at a 
3.00 value. The final $\mathrm{pH}$ value after treatment was 2.95. The residual iron had a value of $6.67 \mathrm{mg} \mathrm{L}^{-1}$ and residual $\mathrm{H}_{2} \mathrm{O}_{2}$ of $0.42 \mathrm{mg} \mathrm{L}^{-1}$.

After the treatments, there continued to be a problem concerning the discharge of the organic matter, which reached a COD value of $595.95 \mathrm{mg} \mathrm{O}_{2} \mathrm{~L}^{-1}$, and thus failed to reach the minimum value (450.00 $\mathrm{mgO}_{2} \mathrm{~L}^{-1}$ ) stipulated by the Brazilian Resolution of 2009 (AGR, 2009). For this reason, the use of combined slow filtration with coagulation/flocculation processes was recommended together with the Fenton reagent discussed above. This was used for final polishing with the aim of meeting current standards of effluent release in water bodies and, perhaps later, the end of reuse for non-potable purposes.

\subsection{Slow Filtration Treatment}

After the treatment by Fenton reaction, the $\mathrm{pH}$ was raised to 7.00. The $\mathrm{pH}$ around 7.00 favors the growth of microorganisms that are essential for the development of the biological layer ("schmutzdecke") at the top of sand layer and benefits from a good performance of the slow filter (Nascimento et al., 2012).

The main parameter, which is still failing to comply with federal legislation regarding COD, reached a parameter for disposal ranging from $595.95 \mathrm{mg} \mathrm{O}_{2} \mathrm{~L}^{-1}$ to $346.21 \mathrm{mg} \mathrm{O}_{2} \mathrm{~L}^{-1}$ in the best treatment batch.

After the fourth treatment batch, the slow filter starts the clogging process and it is necessary to clean the non-woven synthetic blankets on top of the sand filter layer before starting treatment again.

After the integration of technologies in these studies, the following analyses were performed before and after proposed treatments and properly discussed as follows.

\subsection{Analysis of the Parameters Investigated}

In the study of $\mathrm{pH}$ values, it was observed that after the treatment by coagulation/flocculation, there is a reduction of the $\mathrm{pH}$ value which achieves a final value of 5.81. This is due to hydrolysis of iron which releases protons $\left(\mathrm{H}^{+}\right)$during the formation of hydroxylating species of iron in the reaction medium (Marcionilio et al., 2015).

In the treatment of the Fenton reagent, the initial $\mathrm{pH}$ value was 3.00, but at the end of the process, this value changed to 2.95. This reduction is due to the release of $\mathrm{H}^{+}$ions during the regeneration process of the catalyst represented in Equations 10 and 11 (Sohrabi et al., 2017).

$$
\begin{aligned}
& \mathrm{Fe}^{3+}+\mathrm{H}_{2} \mathrm{O}_{2} \rightarrow \mathrm{FeOOH}^{2+}+\mathrm{H}^{+} \quad \mathrm{K}=0.001-0.01 \mathrm{~L} \mathrm{~mol}^{-1} \mathrm{~s}^{-1} \\
& \mathrm{FeOOH}^{2+} \rightarrow \mathrm{Fe}^{2+}+\mathrm{HO}_{2}^{\bullet} \quad \mathrm{K}=2.7 \times 10^{-3} \mathrm{~L} \mathrm{~mol}^{-1} \mathrm{~s}^{-1}
\end{aligned}
$$

The decomposition of the hydroperoxyl radical also triggers the release of protons in medium (Equation 12) (Giannakis et al., 2016).

$$
\mathrm{HO}_{2}^{\bullet} \rightarrow\left(\mathrm{O}_{2}^{\circ-}\right)+H^{+} \quad \mathrm{K}=1.58 \times 10^{5} \mathrm{~L} \mathrm{~mol}^{-1} \mathrm{~s}^{-1}
$$

The reaction between ferric ion and the hydroperoxyl radical also leads to the regeneration of ferrous ions with a release of oxygen gas and $\mathrm{H}^{+}$ions, as expressed in Equation 13 (Babuponnusami and Muthukumar, 2014).

$$
\mathrm{Fe}^{3+}+\mathrm{HO}_{2}^{\bullet} \rightarrow \mathrm{Fe}^{2+}+\mathrm{O}_{2}+\mathrm{H}^{+} \quad \mathrm{K}=0.33-2.1 \times 10^{6} \mathrm{~L} \mathrm{~mol}^{-1} \mathrm{~s}^{-1}
$$

At the end of the integration of the treatment technologies, the final $\mathrm{pH}$ value was 6.93, which is within the allowed range for disposal (between 5-9) according to Brazilian legislation (Pompei et al., 2017). 
With regard to the absorbance analysis, it should be noted that at a wavelength of $320 \mathrm{~nm}$ researchers have found the presence of aromatic rings in solution. In addition, it is reported that at wavelengths of 200 to $300 \mathrm{~nm}$, the main structures are carbonyl, carboxyl, nitroso and nitrite. At $292 \mathrm{~nm}$, the most likely compounds are: aromatic amino acids and highly conjugated aliphatic chain volatile compounds, at $328 \mathrm{~nm}$ naphthalene and its derivatives (Hu and Wang, 2017).

Colored organic compounds have a chromophore group attached to a conjugated double bonds system. These chromophoric groups have unsaturated bonds such as $\mathrm{C}=\mathrm{O}$ and $\mathrm{N}=\mathrm{N}$ (Durigan et al., 2012).

Within this scenario for absorbance analysis, it was noted that during the post-reaction Fenton treatment, there was an increase of $65.71 \%$ of absorbance at $200 \mathrm{~nm}$, possibly owing to the generation of intermediates that are strongly absorbent at this wavelength. According to $\mathrm{Hu}$ and Wang (2017), at 200-250 nm absorbance, the values may represent carboxyl functional groups that are strongly absorbent in this range.

The overall final removals of absorbance in this study were $83.50 \%$ at $200 \mathrm{~nm}$ and $86.25 \%$ at $320 \mathrm{~nm}$ for 400 minutes of treatment.

With regard to the turbidity analysis, the crude effluent showed a value of $134.40 \mathrm{NTU}$, and the final value obtained was 0.78 NTU in accordance with the limits allowed by Brazil 2005 (Conama, 2005), which establishes a value below 40.00 NTU in Class 1 waters. After crude laboratory effluent is treated by the coagulation/flocculation process, it already acquires a value of $4.1 \mathrm{NTU}$, which is within the limits imposed by federal legislation. After integrating three technologies, it was possible to obtain $99.41 \%$ of the removal value of this analytical parameter.

In the analysis of total soluble iron, the treated laboratory effluent had a total residual soluble iron concentration of $0.56 \mathrm{mg} \mathrm{L}^{-1}$, after combined treatments. Compared with the crude laboratory effluent, this value obtained a reduction of $99.32 \%$ with regard to the initial concentration of total soluble iron (82.49 $\mathrm{mg} \mathrm{L}^{-1}$ ).

In the same way as in the first turbidity stage of coagulation/flocculation treatment, the greatest removal value of this parameter (iron) was $96.19 \%$. This was due to the formation of iron hydroxylating species that interacts with colloids of medium to form cohesive flakes with good sedimentability; the action of the anionic polymer is of considerable importance for the interaction of the $\mathrm{Fe}^{2+} / \mathrm{Fe}^{3+}$ ions and reducing their availability to aqueous medium (Ma and Xia, 2009).

The slow filtration process is also responsible for the removal of iron that enters in the treatment system with a concentration of $7.54 \mathrm{mg} \mathrm{L}^{-1}$ and has a final value of $0.56 \mathrm{mg} \mathrm{L}^{-1}$. The processes of straining, sedimentation, inertial impaction, interception, adhesion, flocculation, diffusion, adsorption and biological activity (a microbial consortium called "schmutzdecke", which is described above and which consumes iron and manganese) have been suggested as mechanisms that can be employed for contaminant removal in slow filtration (Bagundol et al., 2013). In this way, soluble iron concentration also reaches parameters for disposal that comply with Resolution Brazil 2011 (Conama, 2011) which provides a maximum of $15 \mathrm{mg} \mathrm{L}^{-1}$ of total iron for disposal in hidric bodies.

The Residual hydrogen peroxide in crude laboratory effluent had a concentration of $1.13 \mathrm{mg} \mathrm{L}^{-1}$. During the second stage, the Fenton reaction added $200.00 \mathrm{mg} \mathrm{L}^{-1}$ of $_{2} \mathrm{H}_{2}$ where almost all of the $\mathrm{H}_{2} \mathrm{O}_{2}$ was consumed during the homogeneous catalytic process (phase 1 of Fenton Equation 3) with a final concentration after the Fenton reaction of $0.41 \mathrm{mg} \mathrm{L}^{-1}$ and overall removal with combination treatments of $92.92 \%$.

The removal of this value is extremely important because hydrogen peroxide is an oxidizing agent $(1.42 \mathrm{~V})$ that can continue the process of oxidation in aqueous medium if it 
does not decompose rapidly in water and molecular oxygen (Brito et al., 2015). In addition, the high presence of $\mathrm{H}_{2} \mathrm{O}_{2}$ prevents a visualization of spectral changes in wavelengths between 200$300 \mathrm{~nm}$, although in this article it was possible to determine the decrease of signals in these regions, which may indicate a degradation of aromatic intermediates (Salvador et al., 2012).

Through the analysis of the Chemical Oxygen Demand, it was possible to achieve an overall removal of $75.27 \%$ with a final COD of $346.21 \mathrm{mg} \mathrm{O}_{2} \mathrm{~L}^{-1}$, thus obtaining a parameter for disposal that is in compliance with Brazilian Resolution 2009 (AGR, 2009), which recommends a final disposal of COD in the order of $450.00 \mathrm{mg} \mathrm{O}_{2} \mathrm{~L}^{-1}$. The Fenton reaction, which is technology that involves the oxidation of organic matter, contributed to $30.40 \%$ of the removal. Fenton's reagent is an extremely promising remediation technology because it has a relatively low cost and high degree of efficiency compared with other advanced oxidations.

The dissolved oxygen (DO) analysis in crude laboratory effluent showed a value of $1.70 \mathrm{mg} \mathrm{L}^{-1}$, a value that can be explained by the high organic load and oils and greases present in the studied effluent. After treatment with Fenton's reagent, the final dissolved oxygen concentration was $4.70 \mathrm{mg} \mathrm{L}^{-1}$, which is an increase of $63.82 \%$ in the value of this parameter.

The intermediate reactions of the Fenton process explains the increase of $\mathrm{O}_{2}$ concentration in the treated wastewater, hydroperoxyl radical in an aqueous solution is formed in reaction to Phase 02 during the regeneration of the catalyst. This leads to a reduction of ferric ions to ferrous ions and forming oxygen gas and acidifying medium (Equation 13) (Morais and Brito, 2016).

$$
\mathrm{Fe}^{3+}+\mathrm{HO}_{2}^{\cdot} \rightarrow \mathrm{Fe}^{2+}+\mathrm{O}_{2}+\mathrm{H}^{+} \quad \mathrm{K}=0.33-2.1 \times 10^{6} \mathrm{~L} \mathrm{~mol}^{-1} \mathrm{~s}^{-1}
$$

According to Frade (2013), the hydroperoxyl radical still undergoes decomposition and generates a superoxide radical $\left(\mathrm{O}_{2}{ }^{-}\right)$, since it is involved in the reduction cycle between $\mathrm{Fe}^{+2}$ and $\mathrm{Fe}^{+3}$. It also leads to an increase of concentration of $\mathrm{O}_{2}$ in treated wastewater (Equations 12, 14 and 15).

$$
\begin{array}{ll}
\mathrm{HO}_{2}^{\bullet} \rightarrow\left(\mathrm{O}_{2}^{\bullet-}\right)+\mathrm{H}^{+} & \mathrm{K}=1.58 \times 10^{5} \mathrm{~L} \mathrm{~mol}^{-1} \mathrm{~s}^{-1} \\
\mathrm{Fe}^{2+}+\mathrm{O}_{2}^{\bullet-} \rightarrow \mathrm{Fe}^{3+}+\mathrm{O}_{2}^{-2} & \mathrm{~K}=1 \times 10^{7} \mathrm{~L} \mathrm{~mol}^{-1} \mathrm{~s}^{-1} \\
\mathrm{Fe}^{3+}+\left(\mathrm{O}_{2}^{\circ-}\right) \rightarrow \mathrm{Fe}^{2+}+\mathrm{O}_{2} & \mathrm{~K}=5 \times 10^{7} \mathrm{~L} \mathrm{~mol}^{-1} \mathrm{~s}^{-1}
\end{array}
$$

In addition, residual hydrogen peroxide releases water and oxygen gas during its decomposition, and thus increases the DO concentration in treated effluent. It is worth noting that the decrease of the concentration of organic matter and the aeration in the jar test can also assist in increasing the dissolved oxygen.

After treatment by slow filtration, there was a reduction in the DO value and the final value was $3.22 \mathrm{mg} \mathrm{L}^{-1}$ at the end of the integration of the technologies, which included the following: physical absorption in the non-woven synthetic blanket, adsorption of chemicals in the sand layers and biological processes. For instance, dissolved organic material may be trapped in the filter that is adsorbed and metabolized by microorganisms. All these phenomena may affect the variation of the DO values (Arantes et al., 2014).

In the case of the phenolic compounds, crude laboratory effluent showed a high concentration of $84.83 \mathrm{mg} \mathrm{L}^{-1}$, during combined treatments. It showed a $94.12 \%$ reduction with a final value of $4.98 \mathrm{mg} \mathrm{L}^{-1}$, despite the fact that high reduction treated effluent is not suitable for the release standards established by Brazilian legislation of 2011. This has a maximum concentration of $0.5 \mathrm{mg} \mathrm{L}^{-1}$ of total phenols as a standard for the discharge of effluent, and requires other technologies to provide guidelines for the phenols.

\section{IPABH}

Rev. Ambient. Água vol. 13 n. 5, e2243 - Taubaté 2018 
The oils and greases parameter was determined for the crude laboratory effluent after the three treatment technologies had been combined, namely i): coagulation/flocculation; ii) the Fenton reaction; and iii) slow filtration resulting in a reduction of $99.10 \%$, which is a significant value in percentage terms. The values fell from $134.60 \mathrm{mg} \mathrm{L}^{-1}$ in crude laboratory effluent to $1.20 \mathrm{mg} \mathrm{L}^{-1}$ in post-filtration effluent during 400 minutes of treatment. The final result of $1.20 \mathrm{mg} \mathrm{L}^{-1}$ is a much lower value than the established threshold in Brazilian Resolution 2011 (Conama, 2011) for mineral oils up to $20 \mathrm{mg} \mathrm{L}^{-1}$ and $50 \mathrm{mg} \mathrm{L}^{-1}$ for vegetable oils and animal fats.

In the analysis of total organic carbon, the crude laboratory effluent showed a total organic carbon (TOC) value of $56.42 \mathrm{mg} \mathrm{L}^{-1}$ after combined treatments, a reduction of $87.54 \%$ with a final value of $7.02 \mathrm{mg} \mathrm{L}^{-1}$. The results showed that combined processes are efficient, not only in degrading organic compounds, but also perhaps in the degradation that is continued until a complete mineralization.

When the COD value (1400.49 $\mathrm{mg} \mathrm{O}_{2} \mathrm{~L}^{-1}$ ) and TOC value (56.42 $\mathrm{mg} \mathrm{L}^{-1}$ ) were calculated for crude laboratory effluent, the value obtained in TOC / COD ratio was 0.04. After treatment, COD and TOC values reached $346.21 \mathrm{mg} \mathrm{O}_{2} \mathrm{~L}^{-1}$ and $7.02 \mathrm{mg} \mathrm{L}^{-1}$ respectively. The TOC/COD ratio fell to 0.02 , which is indicative of the destruction of heteroatomic groups and unsaturations (Aquino et al., 2006; Morais and Brito, 2015; 2016).

In an analysis of the solids series for this type of effluent, there are no settleable solids and the most significant results are a $54.73 \%$ increase over total fixed solids treatment. This increase over total fixed solids treatment represents an estimate of inorganic matter, an interesting fact that shows the mineralization of organic compounds in $\mathrm{CO}_{2}, \mathrm{H}_{2} \mathrm{O}$ and inorganic ions. In the analysis of total volatile solids that represent an estimate of organic matter, there was an overall reduction of 74.49\%, a result that can be regarded as significant (Munoz et al., 2012).

\subsection{Reuse of wastewater for non-potable purposes.}

The criteria and guidelines used to determine the possibility of reusing treated liquid effluents, were based on publications from government agencies such as ABNT (1997) and USEPA (2012), as well as from Oenning Junior and Pawlowsky (2007); Tonetti et al., (2012); and Da Silva and Santana (2014).

In this article, a study was carried out of two guidelines mentioned previously and a summary was made of the limit values of the main analytical parameters, that included the feasibility of reuse for non-potable purposes.

The parameters studied for this purpose were as follows: $\mathrm{pH}$, total iron, COD, dissolved oxygen, turbidity, Total Organic Carbon (TOC) and oils and greases.

The analytical parameters $\mathrm{pH}$ (6.73), total iron $\left(0.56 \mathrm{mg} \mathrm{L}^{-1}\right)$, dissolved oxygen (DO $\left.3.22 \mathrm{mg} \mathrm{L}^{-1}\right)$, turbidity (0.78 NTU) and total organic carbon $\left(7.02 \mathrm{mg} \mathrm{L}^{-1}\right)$ are below the thresholds set by the guidelines with regard to reuse for non-potable purposes.

The values for reuse (non-potable purposes) are:

- $\mathrm{pH}$ value 6-9

- Total iron $\leq 5.00 \mathrm{mg} \mathrm{L}^{-1}$

$-\mathrm{DO} \geq 2.00 \mathrm{mg} \mathrm{L}^{-1}$

- Turbidity $\leq 30 \mathrm{NTU}$

- $\mathrm{TOC} \leq 10.00 \mathrm{mg} \mathrm{L}^{-1}$

However, the COD analyses (346.21 $\left.\mathrm{mg} \mathrm{O}_{2} \mathrm{~L}^{-1}\right)$ and oils and greases $\left(1.20 \mathrm{mg} \mathrm{L}^{-1}\right)$ did not reach the thresholds set by the cited guidelines. 
The values for reuse (non-potable purposes) are:

$-\mathrm{COD} \leq 90.00 \mathrm{mg} \mathrm{O}_{2} \mathrm{~L}^{-1}$

- Oils and greases $\leq 0.05 \mathrm{mg} \mathrm{L}^{-1}$

When adopting an approach using only Brazilian legislation (ABNT, 1997), DO, Oils and greases, settleable solids and $\mathrm{pH}$ values were included in Class A for reuse for surface water recharge (the dam designed for public supply, or for rivers up to $10 \mathrm{~km}$ upstream of this dam, regardless of the distance from the catchment point and reservoir volume).

\section{CONCLUSION}

The optimum concentrations of anionic polymer, $\mathrm{Fe}^{+2}, \mathrm{H}_{2} \mathrm{O}_{2}$ and $\mathrm{pH}$ values were obtained during a treatment that integrated coagulation/flocculation with the Fenton treatment followed by slow filtration. They had the following values: Coagulation/Flocculation (total iron= $82.49 \mathrm{mg} \mathrm{L}^{-1}$, anionic polymer $=0.80 \mathrm{mg} \mathrm{L}^{-1}$ and $\mathrm{pH}=6.00$ ), Fenton reagent (total iron $=13.00 \mathrm{mg} \mathrm{L}^{-1}, \mathrm{H}_{2} \mathrm{O}_{2}=200.00 \mathrm{mg} \mathrm{L}^{-1}$ and $\mathrm{pH}=3.00$ ) and slow filtration $(\mathrm{pH}=7.00$ and filtration rate $3 \mathrm{~m}^{3} \mathrm{~m}^{-2} \cdot \mathrm{d}^{-1}$ ).

The coagulation/flocculation/Fenton reagent followed by slow filtration showed the main final removals: $75.27 \%$ COD removal with a final value of $346.21 \mathrm{mgO}_{2} \mathrm{~L}^{-1} ; 83.50 \%$ absorbance removal $(200 \mathrm{~nm})$ displaying a final value of $0.94 ; 86.25 \%$ absorbance removal $(320 \mathrm{~nm})$ with a final value of 0.22 and $99.41 \%$ turbidity removal with final turbidity of 0.78 NTU. The total treatment time was 400 minutes.

The levels of total organic carbon (TOC) in treated effluent were evaluated by assessing the efficiency of the organic matter removal. The effluent treated at the end of the integration showed a reduction of $87.54 \%$ with a final value of $7.02 \mathrm{mg} \mathrm{L}^{-1}$; it can thus be concluded that combined treatments are efficient in the removal of organic compounds and can lead to degradation in the form of a complete mineralization.

The possibility of reuse for non-potable purposes of laboratory effluent when the obtained results are compared is established through values based on a set of guidelines. It can be concluded that treated effluent is not feasible for reuse, since it is necessary to increase the efficiency of the treatment by conducting more stages of treatment or improving the studied technologies, as well as monitoring other analytical parameters.

\section{ACKNOWLEDGEMENTS}

The authors would like to thank CAPES for the scholarship granted to Master's Degree student Chrystopher Allan Miranda Pereira.

\section{BIBLIOGRAPHICAL REFERENCES}

AGÊNCIA GOIANA DE REGULAÇÃO, CONTROLE E FISCALIZAÇÃO DE SERVIÇOS PÚBLICOS - AGR. Resolução n ${ }^{\circ}$ 68/2009. Dispõe sobre o Regulamento dos Serviços de Abastecimento de Água e de Esgotamento Sanitário da empresa de Saneamento de Goiás S/A. Diário Oficial [de] Goiás, n. 20601, 24 abr. 2009.

AMERICAN PUBLIC HEALTH ASSOCIATION - APHA. Standard Methods for the Examination of Water and Wastewater. 20. ed. New YorK, 1998. 
AQUINO, S. F.; SILVA, S. Q.; CHERNICHARO, C. A. Considerações práticas sobre o teste de demanda química de oxigênio (DQO) aplicado à análise de efluentes anaeróbios. Revista de Engenharia Sanitária Ambiental, v. 11, n. 4, p. 295-304, 2006.

ARANTES, C. C.; RIBEIRO, T. A. P.; PATERNIANI, J. E. S.; SLUSSAREK, M.; SILVA, G. K. E. Uso de coagulantes naturais à base de moringa oleífera e tanino como auxiliadores da filtração em mantas sintética não tecidas. Engenharia Agrícola, v. 34, p.780-788, 2014.

ASHRAFI, M.; CHAMJANGALI, M. A.; BAGHERIAN, G.; GOUDARZI, N. Application of linear and non-linear methods for modeling removal efficiency of textile dyes from aqueous solutions using magnetic $\mathrm{Fe}_{3} \mathrm{O}_{4}$ impregnated onto walnut shell. Spectrochimica Acta Part A: Molecular and Biomolecular Spectroscopy, v. 171, p. 268-279, 2017. https://doi.org/10.1016/j.saa.2016.07.049

ASSOCIAÇÃO BRASILEIRA DA INDÚSTRIA DE HIGIENE PESSOAL, PERFUMARIA E COSMÉTICOS - ABIHPEC. Panorama do setor de HPPC. 2016, disponível em: https://goo.gl/csg5Nt. Acesso em: 20 mar. 2017.

ASSOCIAÇÃO BRASILEIRA DE NORMAS TÉCNICAS - ABNT. Nbr 13969: tanques sépticos - unidade de tratamento complementar e disposição dos efluentes líquidos projeto, construção e operação. Rio de Janeiro, 1997.

BABUPONNUSAMI, A.; MUTHUKUMAR, K. A review on Fenton and improvements to the Fenton process for wastewater treatment. Journal of Environmental Chemical Engineering, v. 2, p. 557-572, 2014. https://doi.org/10.1016/j.jece.2013.10.011

BANERJEE, P.; DEY, S. S.; SWARNAKAR, S.; MUKHOPADHYAY, A.; GHOSH, S. Treatment of cosmetic effluent in different configurations of ceramic UF membrane based bioreactor: Toxicity evaluation of the untreated and treated wastewater using catfish (Heteropneustes fossilis). Chemosphere, v. 146, p. 133-144, 2016. https://doi.org/10.1016/j.chemosphere.2015.12.004

BAGUNDOL, T. B.; AWA, A. L.; ENGUITO, M. R. Efficiency of slow sand filter in purifying well water. Journal Multidisciplinary Studies, v. 2, n. 1, 2013.

BRITO, N. N.; PATERNIANI, J. E. S.; BROTA, G. A.; PELEGRINI, R. T. Ammonia removal from leachate by photochemical process using $\mathrm{H}_{2} \mathrm{O}_{2}$. Revista Ambiente \& Água, v. 5, p. 51-60, 2010.

BRITO, N. N.; LEITE, A. G. C.; CRUZ, T. M. G. S.; LIMA, T. C. R.; BORGES, F. A. Remediação de corante dispersivo utilizando tecnologia de tratamento: Fotoquímica $\mathrm{H}_{2} \mathrm{O}_{2}$ /Vis. Química Têxtil, v. 118, p. 36-52, 2015.

CAVALCANTE, A. M. Técnicas oxidativas para a remoção de matéria orgânica de uma corrente de soda exausta de refinaria de petróleo. 2005. 145p. Dissertação (Mestrado) - Universidade Federal do Rio de Janeiro, Rio de Janeiro, 2005.

CONSELHO NACIONAL DO MEIO AMBIENTE - CONAMA. Resolução nº 357, de 17 de março de 2005. Dispõe sobre a classificação dos corpos de água e diretrizes ambientais para o seu enquadramento, bem como estabelece as condições e padrões de lançamento de efluentes, e dá outras providências. Diário Oficial [da] União, n. 53, p. 58-63, 18 mar. 2005. 
CONSELHO NACIONAL DO MEIO AMBIENTE - CONAMA. Resolução nº 430, de 13 de maio de 2011. Dispõe sobre as condições e padrões de lançamento de efluentes, complementa e altera a Resolução n ${ }^{\circ}$ 357, de 17 de março de 2005, do Conselho Nacional do Meio Ambiente - CONAMA. Diário Oficial [da] União, n. 92, p. 89, 16 maio 2011.

DA SILVA, M. A.; SANTANA, C. G. Reuso de água: Possibilidades de redução do desperdício nas atividades domésticas. Periódico do centro de estudos em desenvolvimento sustentável da UNDB, n. 1, p. 1-14, 2014.

DURIGAN, M. A. B.; VAZ, S. R.; PERALTA-ZAMORA, P. Degradação de poluentes emergentes por processo Fenton e Foto Fenton. Química Nova, v. 35, n. 7, p. 1381-1387, 2012.

FRADE, V. M. F. Oxidação química de enrofloxacina pelo processo Fenton. 2013. 193p. Dissertação (Mestrado em Tecnologia Químico-Farmacêutica) - Faculdade de Ciências Farmacêuticas, Universidade de São Paulo, São Paulo, 2013. http://dx.doi.org/10.11606/D.9.2013.tde-27032014-162133

GAMA, M. R. Processos Fenton como Alternativa na Remoção de Interferentes Endócrinos e outros Micropoluentes Ambientais. Revista Virtual de Química, v. 4, n. 6, p. 777-787, 2012. http://dx.doi.org/10.5935/1984-6835.20120056

GIANNAKIS, S.; LÓPEZ, S. M. I. P.; SPUHLER, D.; PÉREZ, J. A. S.; IBÁNEZ, P. F.; PULGARIN, C. Solar disinfection is an augmentable, in situ-generated photo-Fenton reaction-Part 1: A review of the mechanisms and the fundamental aspects of the process. Applied Catalysis B: Environmentalv. 199, p. 199-223, 2016. https://doi.org/10.1016/j.apcatb.2016.06.009

GUO, J. S.; ABBAS, A. A.; CHEN, Y.P.; LIU, Z. P.; FANG, F.; CHEN, P. Treatment of landfill leachate using a combined stripping, Fenton, SBR, and coagulation process. Journal of $\begin{array}{lllll}\text { Hazardous } & \text { Materials, } & \text { v. }\end{array}$ https://doi.org/10.1016/j.jhazmat.2010.01.144

HU, Y.; WANG, X. Application of surrogate parameters in characteristic UV-vis absorption bands for rapid analysis of water contaminants. Sensors and Actuators B: Chemical, v. 239, p. 718-726, 2017. https://doi.org/10.1016/j.snb.2016.08.072

KHANDARE, R. V.; GOVINDWAR, S. P. Phytoremediation of textile dyes and effluents: Current scenario and future prospects. Biotechnology Advances, v. 33, p. 1697-1714, 2015. https://doi.org/10.1016/j.biotechadv.2015.09.003

LIN, M.; NING, X.; AN, T.; ZHANG, J.; CHEN, C.; KE, Y. et al. Degradation of polycyclic aromatic hydrocarbons (PAHs) in textile dyeing sludge with ultrasound and Fenton processes: Effect of system parameters and synergistic effect study. Journal of $\begin{array}{llllll}\text { Hazardous } & \text { Materials, } & \text { v. } & \text { 307, } & \text { p. } & 7-16,\end{array}$ https://doi.org/10.1016/j.jhazmat.2015.12.047

MA, X. J.; XIA, H. L. Treatment of water-based printing ink wastewater by Fenton process combined with coagulation. Journal of Hazardous Materials, v. 162, p. 386-390, 2009. https://doi.org/10.1016/j.jhazmat.2008.05.068

MARCIONILIO, S. M. L. O.; BARROS, V. S; LÉON, J. J. L. Avaliação da coagulação química e eletrocoagulação no tratamento de efluente de polo farmacêutico. RQI- Revista Química Industrial, n. 749, p. 22-31, 2015. 
MIRZAEI, A.; CHEN, Z.; HAGHIGHT, F.; YERUSHALMI, L. Removal of pharmaceuticals from water by homo/heterogeneous Fenton-type processes - A review. Chemosphere, v. 174, p. 665-688, 2017. https://doi.org/10.1016/j.chemosphere.2017.02.019

MORAIS, W. O.; BRITO, N. N. Tratamento de efluente de indústria cosmética via reagente de Fenton. Revista de Química Industrial, v. 84, n. 753, p.52-68, 2016.

MORAIS, W. O.; BRITO, N. N. Treatment of simulated wastewater via Fenton reaction at a production line of sunscreen. Oxidation Communications, v. 38, n. 4A, p. 2261-2272, 2015.

MUNOZ, M.; PEDRO, Z. M.; PLIEGO, G.; CASAS, J. A.; RODRIGUEZ, J. J. Chlorinated byproducts from the Fenton-like oxidation of polychlorinated phenols. Industrial e Engineering Chemistry Research, v. 51, p. 13092-13099, 2012. http:dx.doi.org/10.1021/ie3013105

NASCIMENTO, A. P.; PELEGRINI, R. T.; BRITO, N. N. Filtração Lenta para o tratamento de águas para pequenas comunidades rurais. Revista Eletrônica de Engenharia Civil, v. 2, p. 54-58, 2012. https://doi.org/10.5216/reec.v4i2.19705

NOGUEIRA, R. F. P.; TROVÓ, A. G.; SILVA, M. R. A.; VILLA, R. D. Fundamentos e aplicações ambientais dos processos Fenton e foto-Fenton. Química Nova, v. 30, n. 2, p. 400-08, 2007. http://dx.doi.org/10.1590/S0100-40422007000200030

OENNING JUNIOR, A.; PAWLOWSKY, U. Avaliação de tecnologias avançadas para o reuso de águas em indústria metal-mecânica. Engenharia Sanitária e Ambiental, v. 12, n. 3, p. 305-316, 2007. https://doi.org/10.1590/S1413-41522007000300010

OLIVEIRA, M. C.; NOGUEIRA, R. F. P.; GOMES NETO, J. A.; JARDIM, W. F.; ROHWEDDER, J. J. R. Sistema de injeção em fluxo espectrofotométrico para monitorar peróxido de hidrogênio em processo de fotodegradação por reação foto-fenton. Química Nova, v. 24, n. 2, p. 188-190, 2001. http://dx.doi.org/10.1590/S010040422001000200007

POMPEI, C. M. E.; CIRIC, L.; CANALES, M.; KARU, K.; VIEIRA, E. M.; CAMPOS, L. C. Influence of PPCPs on the performance of intermittently operated slow sand filters for household water purification. Science of The Total Environment, v. 581-582, p. 174185, 2017. https://doi.org/10.1016/j.scitotenv.2016.12.091

QUARTAROLI, L.; KURITZA, J. C.; CAVALLINI, G. S.; VIDAL, C. M. S.; SOUZA, J. B. Aplicação de polímeros aniônico e catiônico na flotação por ar dissolvido como forma de pós-tratamento de efluente de indústria de papel e celulose. Scientia Forestalis, v. 42, n. 101, p. 57-67, 2014.

RAGASSON, M. K. Aplicação do reagente Fenton no tratamento de lixiviado de aterros sanitários. Especialize, n. 4, 2013.

SALVADOR, T.; MARCOLINO, L. H.; PERALTA-ZAMORA, P. Degradação de corantes têxteis e remediação de resíduos de tingimento por processos Fenton, Foto Fenton e Eletro Fenton. Química Nova, v. 35, n. 5, p. 932-938, 2012.

SHAIKH, S. M. R.; NASSER, M. S.; HUSSEIN, I. A.; BENAMOR, A. Investigation of the effect of polyelectrolyte structure and type on the electrokinetics and flocculation behavior of bentonite dispersions. Chemical Engineering Journal, v. 311, p. 265-276, 2017. https://doi.org/10.1016/j.cej.2016.11.098 
SEMERARO, P.; RIZZI, V.; FINI, P.; MATERA, S.; COSMA, P.; FRANCO, E. et al. Interaction between industrial textile dyes and cyclodextrins. Dyes and Pigments, v. 119, p. 84-94, 2015. https://doi.org/10.1016/j.dyepig.2015.03.012

SOHRABI, M. R.; KHAVARAN, A.; SHARIATI, S.; SHARIATI, S. Removal of Carmoisine edible dye by Fenton and photo Fenton processes using Taguchi orthogonal array design. Arabian Journal of Chemistry, v. 10, p. S3523-S3531, 2017. https://doi.org/10.1016/j.arabjc.2014.02.019

TONETTI, A. L.; CORAUCCI FILHO, B.; NICOLAU, C. E.; BARBOSA, M.; TONON, D. Tratamento de esgoto e produção de água de reuso com o emprego de filtro lento. Engenharia Sanitária e Ambiental, v. 17, n. 3, p. 287-294, 2012.http://dx.doi.org/10.1590/S1413-41522012000300005

TORRADESA, F.; MONTAÑOB, J. G. Using central composite experimental design to optimize the degradation of real dye wastewater by Fenton and photo-Fenton reactions. Dyes and Pigments, v. 100, p. 184-189, 2014.

UNITED STATES. Environmental Protection Agency - USEPA. Guidelines for Water Reuse. EPA/600/R-12/618. Washington, DC, 2012. 450 p.

WIŚNIEWSKA, M.; CHIBOWSKI, S.; URBAN, T. Adsorption properties of the nanozirconia/anionic polyacrylamide system-Effects of surfactant presence, solution pH and polymer carboxyl groups content. Applied Surface Science, v. 370, p. 351-356, 2016. https://doi.org/10.1016/j.apsusc.2016.02.188 